\title{
Warunki rozwoju innowacyjności przedsiębiorstw w regionalnej gospodarce opartej na wiedzy
}

https://doi.org/10.33141/po.2005.10.04

Tadeusz A. Grzeszczyk
Przegląd Organizacji, Nr 10 (789), 2005, ss. 20-23 www.przegladorganizacji.pl Towarzystwo Naukowe Organizacji i Kierownictwa (TNOiK)
Przedmiotem artykułu jest zarys modelu warunków innowacyjności przedsiębiorstw w regionalnej gospodarce opartej na wiedzy. Autor konkretyzuje podstawowe założenia Strategii Lizbońskiej przekształcenia obszaru Wspólnoty Europejskiej w najwyżej rozwinięty, konkurencyjny obszar świata, zarządzany wiedzą. Zarysowana koncepcja autora uwzględnia ustalenia Deklaracji z Laeken (The Future of the European Union Laeken Declaration).

\section{Wprowadzenie: przedsiębiorstwo w realizacji Strategii Lizbońskiej}

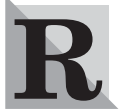

ealizacja Strategii Lizbońskiej implikuje promowanie inwestycji nowych generacji na wiodacych cywilizacyjnie i gospodarczo obszarach Unii Europejskiej. W procesie transformacji, zmiany strukturalne gospodarki krajów Unii Europejskiej i przedsiębiorstw są w znacznym stopniu dofinansowane w coraz szerszym zakresie przez Ramowe Programy Wsparcia Unii Europejskiej (Community Support Framework Programmes). Programy te realizuja politykę socjoekonomicznej spójności krajów Unii Europejskiej, ich regionów oraz przedsiębiorstw do budowy nowego społeczeństwa postindustrialnego, zwanego społeczeństwem innowacyjnym lub społeczeństwem wiedzy (Knowledge Society, Knowledge-driven Economy, Knowledge Management Society, Knowledge Economy, Knowledge-based Economy, Knowledge Management Society).

Gospodarka oparta na wiedzy jest porządkiem ekonomicznym, w którym wiedza, a nie praca, surowce lub kapitał, stanowi dominujący zasób oraz czynnik wzrostu wartości i rozwoju przedsiębiorstwa. System zarządzania wiedzą w przedsiębiorstwie polega na wykreowaniu zinstytucjonalizowanego mechanizmu tworzenia, rozwijania i promowania nowych pomysłów, konstrukcji i technologii oraz zapewnieniu warunków do stałego - a nie okazjonalnego - reagowania na bieżące i przyszłe potrzeby społeczne sygnalizowane przez rynek [Grudzewski, Hejduk 2004, s. 9].

Wiedza w największym stopniu decyduje o tworzeniu wartości dodanej. Efektywne wykorzystywanie wiedzy określa przewagę konkurencyjną każdej organizacji. Współcześnie głównym wyzwaniem dla państw i ich regionów staje się nierówność społeczna wynikająca ze zróżnicowanych warunków dostępu do wiedzy.
Przyszłość należy do organizacji uczących się, zarządzanych wiedzą, do przedsiębiorstw inteligentnych [Gierszewska 2003, s. 62].

Konieczne jest oparcie rozwoju gospodarczego Polski jako całości oraz rozwoju polskich regionów (województw) na wytwarzaniu, transferze i absorpcji wiedzy jako decydującym czynniku generowania wartości dodanej. Istotą koncepcji autora jest stworzenie warunków do generowania endogenicznych czynników rozwoju technologicznego przedsiębiorstwa - powiązanego ze środowiskiem regionalnym - spełniającego wymogi funkcjonowania w warunkach społeczeństwa informacyjnego. Oparciem finansowym dla tego procesu może być sprawna absorpcja funduszy Unii Europejskiej. Absorpcja tych funduszy sprzyja wyzwoleniu zasobów endogenicznych rozwoju regionu oraz przedsiębiorstwa. Zapewni materialne warunki stymulowania procesów innowacji, generowania i transferu zaawansowanych technologii na terenach kluczowych dla rozwoju Unii Europejskiej jako całości.

Tworzenie w naszym kraju podstaw do rozwoju systemu zarządzania wiedzą w regionie i w przedsiębiorstwie oraz do generowania innowacji jest - między innymi - uwarunkowane sprawnym zarządzaniem procesem projektowania przedsięwzięć rozwojowych z dofinansowaniem Unii Europejskiej. Jednakże teoria organizacji i zarzadzania nie sformułowała dotychczas diagnozy warunków wyjściowych sprawności zarządzania ani regionem, ani przedsiębiorstwem w warunkach budowy społeczeństwa informacyjnego z dofinansowaniem Unii Europejskiej. Celem artykułu jest przedstawienie istoty społeczeństwa innowacyjnego i warunków jego implementacji w Polsce. Umożliwi to wstępne sformułowanie zarysu koncepcji zarządzania absorpcją funduszy Unii Europejskiej w przedsiębiorstwie w warunkach budowy nowego społeczeństwa innowacyjnego - jako punktu wyjścia do dyskusji i dalszych badań.

\section{Bariery rozwoju innowacyjności w procesie realizacji Strategii Lizbońskiej}

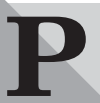

rzeprowadzone badania dowodzą, że zasadniczo niski jest poziom innowacyjności w większości polskich przedsiębiorstw. Kluczową przyczynę stanowią słabości procesu zarządzania innowacjami w przedsiębiorstwie oraz niskie kwa- 
lifikacje kadr menedżerskich w tej dziedzinie. Nie ukształtowały się dotychczas w szerszej skali proinnowacyjne postawy kadr menedżerskich przedsiębiorstw. Brakuje wiedzy możliwej do zastosowania w czasie koniecznym do reagowania na bieżące i nowe, szybko zmieniające się potrzeby rynku krajowego, a tym bardziej brakuje wiedzy o rynkach zagranicznych. Wyraźnie brakuje także sprzężeń zwrotnych między potrzebami ranku a reakcjami proinnowacyjnymi przedsiębiorstw. Niedostatecznie funkcjonuja mechanizmy zasilania finansowego, informacyjnego i technicznego procesów innowacyjnych w przedsiębiorstwie.

W związku z tym konieczne jest stałe diagnozowanie poziomu innowacyjności polskich przedsiębiorstw przy uwzględnieniu zróżnicowań przestrzennych oraz zarysowujących się tendencji zmian. Brakuje efektywnych instrumentów zbierania, przetwarzania, przechowywania i udostępniania informacji dla przedsiębiorstw w dziedzinie zarządzania procesem innowacji w aspektach: technicznym, ekonomicznym, społecznym i prawnym. Odpowiednio do wymienionych wyżej czterech aspektów zarządzania procesem innowacji w przedsiębiorstwie można także mówić o odpowiadających im, czterech grupach przyczyn niedostatecznego poziomu innowacyjności polskich przedsiębiorstw, a także odpowiednio o czterech grupach środ- ków koniecznego działania, to jest: technicznych, ekonomicznych, społecznych i prawnych.

Długotrwały będzie proces przezwyciężania barier rozwoju innowacyjności tkwiących w polskiej gospodarce jako całości, w polskich regionach i w polskich przedsiębiorstwach. Przeprowadzone przez autora badania oraz jego doświadczenia edukacyjne i konsultingowe są kierunkowo zbieżne z zarysowującymi się ocenami dotychczasowego procesu realizacji Strategii Lizbońskiej w krajach Unii Europejskiej. Jak wiadomo, strategia przyjęła swoje kierunkowe cele zbyt ambitnie w relacji do dziesięcioletniego horyzontu czasowego. Mało realne okazuje się zdystansowanie Stanów Zjednoczonych i Japonii w omawianej dziedzinie. Przezwyciężanie barier rozwoju innowacyjności łączy się z realizacją Strategii Lizbońskiej w naszym kraju i szerszej w całej Unii Europejskiej. Badania ujawniają ogólnie niedostateczne efekty dotychczasowych działań Wspólnoty Europejskiej w omawianej dziedzinie. Opóźnienia w realizacji Strategii Lizbońskiej występują nie tylko w Polsce, ale także praktycznie w większości krajów Unii Europejskiej. Z tego powodu przewiduje się dokonanie zasadniczej reorientacji strategii konstruowania i funkcjonowania budżetu Unii Europejskiej w nowym okresie budżetowym na lata 2007-2013 [Structural Policies 2003, Bieliński 2005].

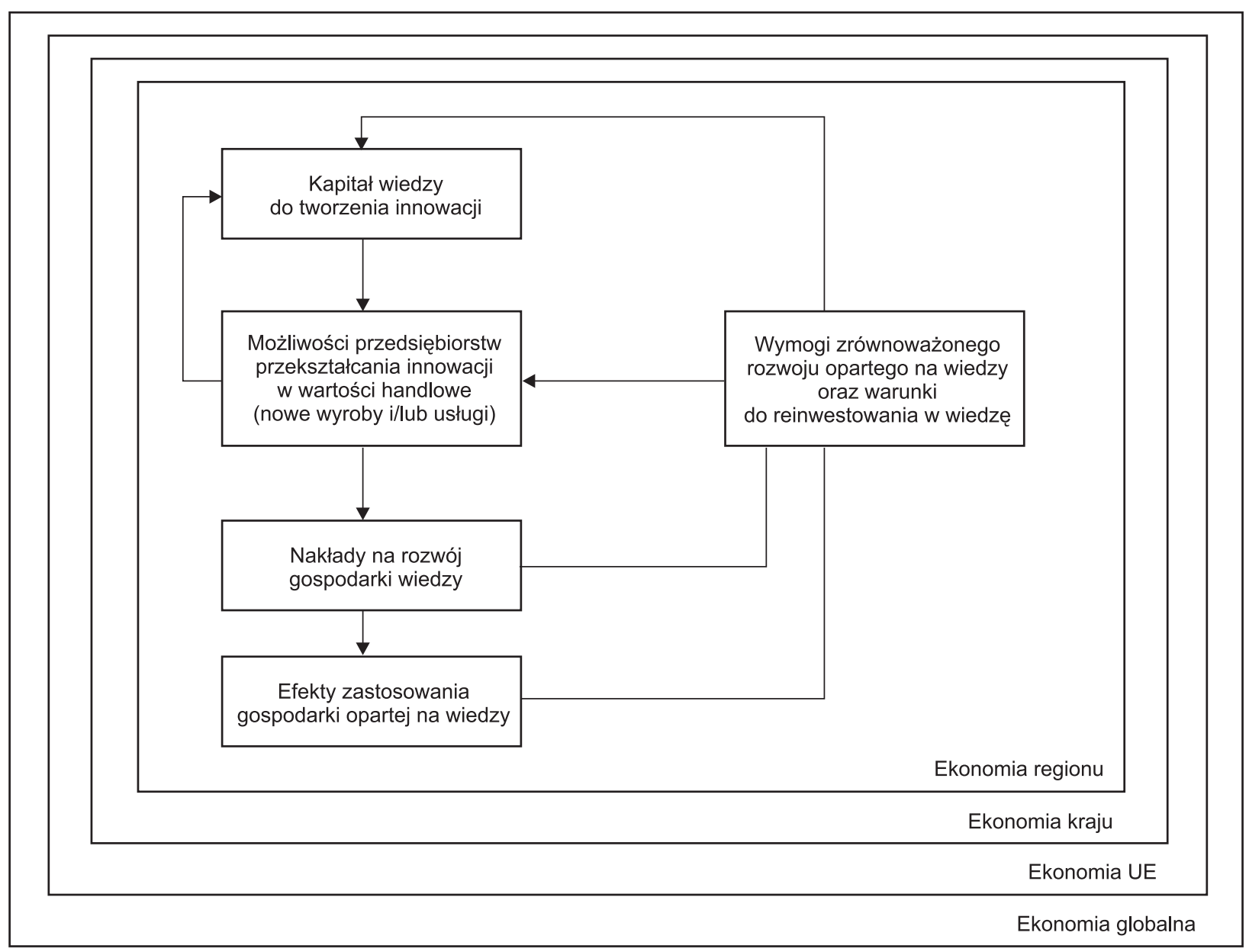

Rys. Model warunków innowacyjności przedsiębiorstw w regionalnej gospodarce opartej na wiedzy Źródło: opracowano na podstawie [HUGGINS, IZUSHI 2001]. 


\section{Efekty realizacji dotychczasowej polityki proinnowacyjnej Unii Europejskiej}

O dpowiednio do przewidywanych tendencji zmian polityki finansowej Unii Europejskiej powstał także rządowy projekt nowego Narodowego Planu Rozwoju na lata 2007-2013. Tworzy to szanse wspólnego przezwyciężania barier rozwoju innowacyjności tkwiących w polskiej gospodarce i polskich przedsiębiorstwach. Jedną z istotnych możliwości przezwyciężania barier rozwoju innowacyjności polskiej gospodarki, polskich regionów i polskich przedsiębiorstw stanowią mechanizmy dofinansowania projektów rozwojowych polskich przedsiębiorstw ze środków uruchamianych funduszami Unii Europejskiej. Stanowi to przedmiot dalszych badań autora. Podstawowe zależności występujące w modelu regionalnej gospodarki opartej na wiedzy obrazuje rysunek.

Regiony zarządzane wiedzą tworzą warunki do formułowania i realizacji nowych koncepcji zarządzania przedsiębiorstwem w społeczeństwie innowacyjnym. Nowa perspektywa finansowa Unii Europejskiej i oparte na niej koncepcje zarządzania funduszami strukturalnymi zasadniczo wzmacniają ten kierunek działania.

Badania procesu zarządzania innowacjami w przedsiębiorstwie nie mogą zostać zdominowane przez wąsko rozumiane aspekty techniczne. Konieczna jest długookresowa perspektywa badawcza aspektów technicznych, ekonomicznych, społecznych i prawnych oparta na wizji Strategii Lizbońskiej. Niezbędne jest szczegółowe badanie efektów i barier realizacji dotychczasowej polityki proinnowacyjnej Unii Europejskiej $\mathrm{w}$ wyżej wymienionych czterech aspektach. Poznanie tych doświadczeń i trudności ułatwia rozwiązywanie problemów i trudności polskich przedsiębiorstw. Trudności te mają charakter techniczny, ekonomiczny, społeczny i prawny.

Generalnie w ciagu ostatnich kilku lat wyraźnemu spowolnieniu uległ wzrost gospodarczy większości krajów Unii Europejskiej. Pozytywnym wyjątkiem jest zarysowująca się dynamika rozwoju gospodarczego Polski. Wzrostowi bezrobocia w krajach Unii Europejskiej towarzyszy jednakże utrzymujący się nadal wysoki jego poziom w naszym kraju (zgodnie z danymi Eurostatu Polska miała największą stopę bezrobocia wśród młodych ludzi w krajach UE: w czerwcu 2005 r. aż 35,6\%). Relatywnie niski jest wzrost wydajności pracy w większości krajów Unii Europejskiej. Aby przeciwdziałać tym tendencjom, przewiduje się w nowym okresie budżetowym Unii Europejskiej w latach 2007-2013 zasadnicze wzmocnienie mechanizmów finansowania procesów innowacyjnych oraz towarzyszacych im inwestycji w kapitał rzeczowy i rozwój zasobów pracy. Dla wzmocnienia działań innowacyjnych w przedsiębiorstwach oraz zwiększenia wydajności pracy i zwalczania bezrobocia przewiduje się zastosowanie w wielkiej skali technologii teleinformatycznych. Odpowiednio, także w Polsce rozwijane są kompleksowe działania Ministerstwa Nauki i Informatyzacji w omawianej dziedzinie. Kluczową rolę odgrywają programy $\mathrm{B}+\mathrm{R}$ oraz integracja technologii i ekonomii w procesie restrukturyzacji polskiej gospo- darki i polskich przedsiębiorstw w celu zasadniczego wzmocnienia ich tendencji innowacyjnych. Istotne znaczenie mają także transeuropejskie programy rozwoju infrastruktury transportowej i komunikacyjnej oraz pomoc publiczna dla przedsiębiorstw ze środków publicznych, w tym ostatnio znaczaca pomoc ze środków Unii Europejskiej [Grzeszczyk 2003].

Pozytywne efekty należy odnotować w dziedzinie promowania ze środków Unii Europejskiej kompleksowych działań wzmacniających konkurencyjność wyrobów i usług krajów członkowskich Wspólnoty, ułatwiających dostęp do rynku i finansujących procesy tworzenia Europejskiej Przestrzeni Badawczej [6FP 2002, www.cordis.lu, www.kpk.gov.pl].

Mimo tych pozytywnych zjawisk, nadal występują wyraźne przejawy nierówności w dostępie do środków Unii Europejskiej, nie tylko polskich przedsiębiorstw, ale także polskiego szkolnictwa wyższego. Dotyczy to zwłaszcza mniejszych, prowincjonalnych ośrodków naukowych i przedsiębiorstw.

Generalnie proces budowy gospodarki opartej na wiedzy został dopiero zapoczątkowany. Dotyczy to w szczególności naszego kraju i innych nowych państw członkowskich Unii Europejskiej.

\section{Przewidywana ewolucja strategii rozwoju Unii Europejskiej i mechanizmów jej finansowania w nowym okresie budżetowym (lata 2007-2013)}

W nowym okresie budżetowym przewiduje się lepsze ukierunkowanie działań interwencyjnych realizujacych polityki szczegółowe Unii Europejskiej. Przewiduje się reformę zasad funkcjonowania tych polityk oraz mechanizmów ich finansowania. Sa to, jak wiadomo, następujące polityki:

- regionalna,

- rolna i rozwoju obszarów wiejskich,

- gospodarcza,

- handlowa,

- w zakresie jednolitego rynku wewnętrznego i konkurencji,

- ochrony środowiska naturalnego,

- kultury,

- badań i rozwoju,

- edukacyjna,

- ochrony zdrowia i zdrowia publicznego.

Konieczne jest zasadnicze wzmocnienie procesów koordynacji i komplementarności funkcjonowania polityk szczegółowych. Nastąpi bardziej przejrzyste wyodrębnienie ramowej struktury priorytetów Unii Europejskiej. Większej koncentracji środków będzie towarzyszyło zasadnicze wzmocnienie procesów kontroli finansowej, a także procesów oceny zgłaszanych projektów (uprzedniej, bieżącej i następczej). Nastapi silniejszy nacisk na osiągane wyniki i ich jakość w kluczowych priorytetach Unii Europejskiej.

Unia Europejska zintensyfikuje działania na rzecz wzmacniania konwergencji - wspierania wzrostu gospodarczego i zwalczania bezrobocia w najmniej rozwiniętych krajach członkowskich Unii Europejskiej $\mathrm{i}$ ich regionach. Bardziej zdecydowanie niż dotychczas będzie poprawiana konkurencyjność w skali całej Unii Europejskiej oraz silniejsze nakierowywanie środków 
finansowych na realizację Strategii Lizbońskiej i rozwój technologiczny wiodących centrów w skali Wspólnoty jako całości.

Nastąpi wzmocnienie działań na poziomie regionów krajów członkowskich oraz pomoc ludziom, a zwłaszcza menedżerom w szybkim reagowaniu na zmiany oraz w adaptowaniu się do tych zmian. Silniejsze działania nastąpią w dziedzinie tworzenia warunków dla klimatu przedsiębiorczości i innowacji zarówno w przedsiębiorstwach, jak również w administracji publicznej (rządowej i samorządowej) [Kok 2004].

W przestrzeni globalnej konkurencji przyjęto, że kwalifikacje kadr menedżerskich stanowią istotny element komparatywnych korzyści Unii Europejskiej. Uznaje się za konieczne zasadnicze wzmocnienie procesów edukacji i podniesienie jej poziomu. Edukacja silniej niż dotychczas powinna być powiązana z życiem zawodowym i trwać praktycznie przez całe życie. Aby zapewniać odpowiednie warunki realizacji tych zadań uruchomiono program Unii Europejskiej Edukacja i Szkolenia.

\section{Zarys koncepcji zarządzania przedsiębiorstwem w warunkach budowy nowego społeczeństwa innowacyjnego}

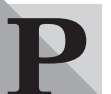

ropozycje autora konkretyzują bogaty dorobek teorii organizacji i zarządzania w dziedzinie przedsiębiorstwa przyszłości, przedsiębiorstwa wirtualnego [Grudzewski, Hejduk 2002], projektowania systemów zarządzania, strategii doskonalenia systemu informacyjnego w zarządzaniu przedsiębiorstwem.

Przeprowadzone badania umożliwiają sformułowanie zarysu koncepcji zarządzania absorpcją funduszy Unii Europejskiej w przedsiębiorstwie w warunkach budowy nowego społeczeństwa innowacyjnego jako punktu wyjścia do dyskusji i dalszych badań. Istotą koncepcji autora jest wiele wzajemnie wspomagających się obszarów. Łączne długookresowe rozwijanie następujących elementów przyczyni się do zasadniczej poprawy poziomu innowacyjności polskich przedsiębiorstw:

- integracja czterech aspektów procesu zarządzania rozwojem innowacji w przedsiębiorstwie, to jest aspektu technicznego, ekonomicznego, społecznego i prawnego;

- stałe prowadzenie badań, edukacji i konsultingu w dziedzinie zarzadzania rozwojem innowacji i ich wdrażania w przedsiębiorstwie przy absorpcji funduszy Unii Europejskiej;

- zasadnicze wzmocnienie uczestnictwa wyższych uczelni technicznych w procesach zarządzania rozwojem innowacji w przedsiębiorstwie przez utrzymywanie trwałej więzi edukacyjnej i konsultingowej z nimi oraz $\mathrm{z}$ zatrudnionymi tam absolwentami;

- stosowanie nowoczesnych programów i technologii kształcenia oraz ich elastyczne harmonizowanie ze zmieniajacymi się potrzebami rynku pracy;

- wytworzenie, rozwinięcie i utrwalenie w kadrze menedżerskiej polskich przedsiębiorstw proinnowacyj- nych postaw, powiązanych z potrzebą ustawicznego doskonalenia kwalifikacji.

\section{Podsumowanie}

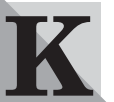

luczową rolę w rozwoju przedsiębiorstwa odgrywa proces doskonalenia kwalifikacji i motywacji pracy $\mathrm{w}$ procesie zarządzania opartym na wiedzy. Istotną rolę w tym procesie może odegrać edukacja.

Efektem aplikacyjnym badań autora jest zarys koncepcji kształcenia w dziedzinie zarządzania rozwojem innowacji w przedsiębiorstwie oraz ich wdrażania. Autor wzmacnia postulaty w dziedzinie implementacji metod sztucznej inteligencji oraz tworzenia warunków rozszerzenia możliwości przedsiębiorstw w dziedzinie absorpcji funduszy Unii Europejskiej. Konieczne jest szersze niż dotychczas zastosowanie nowoczesnych programów i technologii edukacyjnych. Powinny one zapewniać warunki do nabywania wiedzy przydatnej w skali europejskiej, a nawet globalnej, umożliwiającej efektywne wykorzystywanie dofinansowania Unii Europejskiej w projektowaniu przedsięwzięć rozwojowych polskich przedsiębiorstw.

dr inz. Tadeusz A. Grzeszczyk

Instytut Organizacji Systemów Produkcyjnych Politechnika Warszawska

\section{BIBLIOGRAFIA}

[1] 6 FP [2002], The Sixth Framework Programme 20022006, Towards a European Research Area, European Commission, Luxembourg.

[2] BIELIŃSKI J. (red) [2005], Wstęp, [w:] Strategia Lizbońska a konkurencyjność gospodarki, CEDEWU, Warszawa, s. 12.

[3] GIERSZEWSKA G. [2003], Budowanie strategii zarzadzania wiedza w przedsiębiorstwach, [w:] Zarzadzanie wiedza we wspótczesnych organizacjach, red. J. KISIELNICKI, Oficyna Wydawnicza Wyższej Szkoły Handlu i Prawa im. Ryszarda Łazarskiego, Warszawa.

[4] GRUDZEWSKI W.M., HEJDUK I.K. [2002], Przedsiębiorstwo wirtualne, Difin, Warszawa.

[5] GRUDZEWSKI W.M., HEJDUK I.K. [2004], Systemy zarzadzania wiedza - nowy paradygmat czy wyzwanie?, [w:] Przedsiębiorstwo przyszłości. Fikcja i rzeczywistość, red. I.K. HEJDUK, Instytut Organizacji i Zarządzania w Przemyśle ORGMASZ, Warszawa.

[6] GRZESZCZYK T.A. [2003], Rola pomocy publicznej $w$ restrukturyzacji przedsiębiorstw, „Ekonomika i Organizacja Przedsiębiorstwa”, nr 6, s. 46-51.

[7] HUGGINS R., IZUSHI H. [2001], Global Benchmarking of Knowledge Based Regional Economies, red. A. MACONOCHIE, S. HARDY, [w:] Regionalising the Knowledge Econo$m y$, Conference Proceedings of the Regional Studies Association, Annual Conference November 2001, United Kingdom, s. 23-25.

[8] KOK W. (red.) [2004], Facing the Challenge. The Lisbon Strategy for Growth and Employment, Office for Official Publications of the European Communities, Luxembourg.

[9] Structural Policies and European Territories. Competitiveness, Sustainable Development and Cohesion in Europe. From Lisbon to Gothenburg, European Union, Regional Policy, European Commission, Brussels 2003, s. 30-37.

[10] www.cordis.lu

[11] www.kpk.gov.pl 